RT-PCR/MALDI-TOF diagnostic target performance reflects circulating SARS-CoV-2 variant

\title{
diversity in New York City
}

Matthew M. Hernandez ${ }^{1, \#}$, Radhika Banu ${ }^{1}$, Ana S. Gonzalez-Reiche ${ }^{2}$, Brandon Gray ${ }^{1}$, Paras Shrestha ${ }^{1}$,

5 Liyong $\mathrm{Cao}^{1}$, Feng Chen ${ }^{1}$, Huanzhi $\mathrm{Shi}^{1}$, Ayman Hanna ${ }^{1}$, Juan David Ramírez ${ }^{1,3}$, Adriana van de

6 Guchte $^{2}$, Robert Sebra ${ }^{2,4,5,6}$, Mount Sinai PSP Study Group ${ }^{1,2,7}$, Melissa R. Gitman ${ }^{1}$, Michael D.

7 Nowak $^{1}$, Carlos Cordon-Cardo ${ }^{1}$, Ted E. Schutzbank ${ }^{8}$, Viviana Simon ${ }^{1,7,9,10}$, Harm van Bakel ${ }^{2,4}$, Emilia

$8 \quad$ Mia Sordillo ${ }^{1}$, Alberto E. Paniz-Mondolfi, ${ }^{1, \#}$

\section{Affiliations:}

$11{ }^{1}$ Department of Pathology, Molecular, and Cell-Based Medicine, Icahn School of Medicine at Mount 12 Sinai, New York, NY 10029, USA

$13{ }^{2}$ Department of Genetics and Genomic Sciences, Icahn School of Medicine at Mount Sinai, New York, 14 NY 10029, USA

$15{ }^{3}$ Centro de Investigaciones en Microbiología y Biotecnología-UR (CIMBIUR), Facultad de Ciencias 16 Naturales, Universidad del Rosario, Bogotá, Colombia.

$17{ }^{4}$ Icahn Institute for Data Science and Genomic Technology, Icahn School of Medicine at Mount Sinai, 18 New York, NY 10029, USA

$19{ }^{5}$ Black Family Stem Cell Institute, Icahn School of Medicine at Mount Sinai, New York, NY 10029, 20 USA

$21{ }^{6}$ Sema4, a Mount Sinai venture, Stamford, CT 06902, USA

$22{ }^{7}$ Department of Microbiology, Icahn School of Medicine at Mount Sinai, New York, NY 10029, USA

$23{ }^{8}$ Senior Scientific Affairs Manager, Infectious Diseases, Agena Bioscience, San Diego, CA 92121, USA 
medRxiv preprint doi: https://doi.org/10.1101/2021.12.04.21267265; this version posted December 7, 2021. The copyright holder for this preprint (which was not certified by peer review) is the author/funder, who has granted medRxiv a license to display the preprint in perpetuity. It is made available under a CC-BY-NC-ND 4.0 International license.

$24{ }^{9}$ Division of Infectious Diseases, Department of Medicine, Icahn School of Medicine at Mount Sinai, 25 New York, NY 10029, USA

$26{ }^{10}$ The Global Health and Emerging Pathogens Institute, Icahn School of Medicine at Mount Sinai, New 27 York, NY 10029, USA

28

29 \# Corresponding authors: matthew.hernandez@mssm.edu, alberto.paniz-mondolfi@ mountsinai.org

30 Running head: RT-PCR/MALDI-TOF and SARS-CoV-2 variants

31 Keywords: RT-PCR; MALDI-TOF; SARS-CoV-2; Delta; variants; diagnostic; dropout 
medRxiv preprint doi: https://doi.org/10.1101/2021.12.04.21267265; this version posted December 7, 2021. The copyright holder for this preprint (which was not certified by peer review) is the author/funder, who has granted medRxiv a license to display the preprint in perpetuity.

It is made available under a CC-BY-NC-ND 4.0 International license .

\section{Abstract}

As severe acute respiratory syndrome coronavirus 2 (SARS-CoV-2) continues to circulate,

34 multiple variants of concern (VOC) have emerged. New variants pose challenges for diagnostic

35 platforms since sequence diversity can alter primer/probe binding sites (PBS), causing false-negative results. The Agena MassARRAY ${ }^{\circledR}$ SARS-CoV-2 Panel utilizes reverse-transcription polymerase chain reaction and mass-spectrometry to detect five multiplex targets across $N$ and ORFlab genes. Herein, we utilize a dataset of 256 SARS-CoV-2-positive specimens collected between April 11, 2021-August 28,

392021 to evaluate target performance with paired sequencing data. During this timeframe, two targets in 40 the $N$ gene $(\mathrm{N} 2, \mathrm{~N} 3)$ were subject to the greatest sequence diversity. In specimens with N3 dropout, $69 \%$

41 harbored the Alpha-specific A28095U polymorphism that introduces a 3'-mismatch to the N3 forward

42 PBS and increases risk of target dropout relative to specimens with 28095A (relative risk (RR): 20.02;

$43 \mathrm{p}<0.0001 ; 95 \%$ Confidence Interval (CI): 11.36-35.72). Furthermore, among specimens with N2

44 dropout, $90 \%$ harbored the Delta-specific G28916U polymorphism that creates a 3'-mismatch to the N2 45 probe PBS and increases target dropout risk (RR: 11.92; $\mathrm{p}<0.0001 ; 95 \%$ CI: 8.17-14.06). These findings 46 highlight the robust capability of Agena MassARRAY ${ }^{\circledR}$ SARS-CoV-2 Panel target results to reveal 47 circulating virus diversity and underscore the power of multi-target design to capture VOC. 


\section{Introduction}

Since the recognition and global spread of coronavirus disease 2019 (COVID-19), nucleic acid amplification testing has been the diagnostic mainstay for identifying new severe acute respiratory syndrome coranvirus-2 (SARS-CoV-2) infections. Historically, the majority of diagnostic target primers and probes have been designed from viral genomes characterized early in the pandemic. However, in the two years since the first SARS-CoV-2 genome was identified, viral variants have emerged in response to various evolutionary pressures ${ }^{1,2}$. Emergence of variants of concern (VOC) and of interest (VOI) poses a hurdle for diagnostic assays as sequence variation generates mismatches to primer/probe binding sites (PBSs), potentially causing target dropout and false-negative results ${ }^{3,4}$. Failure to promptly detect infections with emerging variants that may be associated with greater transmissibility and infectivity represents a substantive risk for forward transmission in the community.

viral sequence changes are designed to amplify two or more targets across different viral genes (e.g., open reading frame $1 \mathrm{ab}(O R F 1 a b)$, nucleocapsid $(N)$, spike $(S)$, and envelope $(E))$. This redundancy can compensate for individual target dropout due to inherent biochemical differences and analytical sensitivities among targets or due to emergent viral genome diversity at PBS sequences. Several groups have demonstrated the utility of platforms with multiple targets to accurately detect emerging SARSelucidate dynamics of circulating variants in communities. Indeed, multiple reports described the use of

68 dropout of diagnostic targets designed at $S^{5,7,8}$ or $N^{9}$ genes as a screen for PBS-specific polymorphisms 69 that have arisen among emergent SARS-CoV-2 viruses such as the Alpha variant (B.1.1.7 lineage). 
72 increased vaccination rates and infection prevention methods ${ }^{16-18}$, Delta and its sublineages became

73 predominant in New York City (NYC) and abroad ${ }^{10,13,14}$. Given that emergent variants may be

74 associated with resistance to therapeutic antibodies ${ }^{19,20}$, increased transmissibility ${ }^{12,16,21,22}$, or reduced

75 vaccine effectiveness ${ }^{16,17,23,24}$, diagnosing new infections is vital. Several mutation-specific assays have

76 been designed to detect lineage-specific $S$ gene mutations in Delta and older variants ${ }^{25-27}$. However, few

77 assays have been evaluated for their ability to capture contemporary variants in routine clinical settings,

78 or to shed light on sequence diversity in virus genes other than Spike (S).

We recently reported the power of the Agena MassARRAY® SARS-CoV-2 Panel for detection

80 of emergent SARS-CoV-2 variants in NYC during the first months of 2021 and the utility of diagnostic

81 target performance to illuminate sequence diversity among then-predominant Alpha variant genomes ${ }^{28}$.

82 This assay combines reverse-transcription polymerase chain reaction and matrix-assisted laser

83 desorption-ionization time-of-flight mass spectrometry (RT-PCR/MALDI-TOF) to detect five targets in

84 the SARS-CoV-2 genome. Coincident with the spread of the Delta VOC in NYC, we observed a distinct

85 change in the target performance patterns that reflect ongoing viral evolution, prompting us to examine

86 the corresponding genomic sequence data.

87 For the current study, we compared paired RT-PCR/MALDI-TOF diagnostic target data and 88 genome sequencing data for SARS-CoV-2-positive specimens that were collected from April 11, 2021 89 August 28, 2021, and recovered, deidentified, and sequenced as part of the Mount Sinai Health System 90 (MSHS) Pathogen Surveillance Program (PSP) at the Icahn School of Medicine at Mount Sinai 91 (ISMMS). Herein, we utilize a dataset of 256 genomes from SARS-CoV-2-positive clinical specimens 92 to identify PBS mismatches in the $N$ gene and lineage-specific sequence diversity that impacted target 93 performance patterns on the Agena MassARRAY ${ }^{\circledR}$ SARS-CoV-2 Panel. 
medRxiv preprint doi: https://doi.org/10.1101/2021.12.04.21267265; this version posted December 7, 2021. The copyright holder for this preprint (which was not certified by peer review) is the author/funder, who has granted medRxiv a license to display the preprint in perpetuity.

It is made available under a CC-BY-NC-ND 4.0 International license .

\section{Materials and Methods}

\section{Ethics statement}

This study was reviewed and approved by the Institutional Review Board of the ISMMS

97 (HS\#13-00981).

SARS-CoV-2 specimen collection and testing

Upper respiratory tract (e.g., nasopharyngeal, anterior nares) and saliva specimens collected between April 11, 2021 - August 28, 2021 for SARS-CoV-2 diagnostic testing in the Molecular

101 Microbiology Laboratories (MML) of the MSHS Clinical Laboratory, which is certified under Clinical 102 Laboratory Improvement Amendments of 1988, 42 U.S.C. §263a and meets requirements to perform 103 high-complexity tests were eligible for inclusion in this study. Overall, 177,059 upper respiratory and 104 saliva specimens underwent SARS-CoV-2 clinical testing at MSHS MML during the study period, and 105 subset of 256 were deidentified and underwent SARS-CoV-2 next-generation sequencing as previously 106 described ${ }^{28-30}$. For this retrospective study, we utilized deidentified data for diagnostic specimens tested 107 on the Agena MassARRAY ${ }^{\circledR}$ SARS-CoV-2 Panel and MassARRAY ${ }^{\circledR}$ System (Agena, CPM384) 108 platform. Details of processing and SARS-CoV-2 testing of upper respiratory and saliva specimens have 109 been described previously ${ }^{28,31}$.

110 This RT-PCR/MALDI-TOF assay detects five viral targets: three in the nucleocapsid $(N)$ gene 111 (N1, N2, N3) and two in the ORF1ab gene (ORF1A, ORF1AB). Results were interpreted as positive if $\geq$ 1122 targets were detected or negative if $<2$ targets were detected. If no MS2 internal extraction control 113 (IC) and no targets were detected, the result was invalid and required repeat testing of the specimen 114 before reporting. If IC was detected and no targets were detected, the sample was interpreted as 115 negative. 
medRxiv preprint doi: https://doi.org/10.1101/2021.12.04.21267265; this version posted December 7, 2021. The copyright holder for this preprint (which was not certified by peer review) is the author/funder, who has granted medRxiv a license to display the preprint in perpetuity.

It is made available under a CC-BY-NC-ND 4.0 International license .

SARS-CoV-2 sequencing, assembly and phylogenetic analyses

SARS-CoV-2 viral RNA underwent reverse-transcription, PCR amplification and nextgeneration sequencing followed by genome assembly and lineage assignment using a phylogeneticbased nomenclature as described by Rambaut et al. ${ }^{32}$ using the Pangolin v3.1.14 tool and PANGOv1.2.81 nomenclature scheme ${ }^{33}$ as previously described ${ }^{29,30}$. Ultimately, this yielded 244 complete genomes ( $\geq 95 \%$ completeness) and 12 partial genomes ( $<95 \%$ completeness).

\section{Agena target sequence alignment}

Agena MassARRAY ${ }^{\circledR}$ target detection results were matched to the corresponding genome sequences. Primer and probe sequences for each Agena target were obtained from published FDA EUA documentation for the Agena MassARRAY ${ }^{\circledR}$ SARS-CoV-2 Panel (Table S1) ${ }^{34}$. We generated reversecomplement sequences for reverse primers for all five targets and probes that are designed in the reverse orientation (e.g., N1-N3). An unaligned FASTA file including sequence data for the clinical specimens and the Wuhan-Hu-1 reference sequence (NCBI nucleotide: NC_045512.2 (Genbank: MN908947.3)) was generated for each of the fifteen primers/probes. Alignment of specimen sequences with each primer/probe sequence was performed using the Multiple Alignment using Fast Fourier Transform (MAFFT) platform ${ }^{35,36}$ as previously described ${ }^{28}$. To enable inclusion of incomplete genomes that had intact regions sequenced at PBSs, we did not remove uninformative sequences (e.g., with ambiguous letters). Otherwise, the default settings were used to align all sequences to the reference genome, which generated a resulting FASTA alignment file for each primer and probe sequence.

\section{Sequence variation in primer/probe target regions}


To examine sequence diversity at each primer/probe PBS region, nucleotide diversity per 140 basepair was calculated using the PopGenome population genomics analysis package in R (v4.1.2) ${ }^{37}$.

141 Nucleotide diversity per site $(\pi)$ was calculated by dividing the nucleotide diversity of all sequences 142 within each PBS sliding window by the number of nucleotide sites in each corresponding PBS.

143 To identify and calculate mismatch frequency at each PBS, custom Unix-code ${ }^{38}$ was used to

144 identify mismatches at each nucleotide position within each primer and probe sequence as descried 145 previously ${ }^{28}$. PBS mismatch frequency by position of forward/reverse primer and probe sequences were 146 calculated on Microsoft Excel v16.54. To account for differences in completeness of consensus 147 genomes, the number of PBS mismatches was normalized to the number of nucleotides in the PBS of 148 each specimen consensus sequence.

To compare global sequence data for lineages and polymorphisms relevant to this study, we queried publicly-available sequence data from the Global Initiative on Sharing Avian Influenza Data 151 (GISAID) EpiCoV database through their online user interface (https://www.epicov.org, accessed 152 October 16, 2021). Using available filters for collection date ranges, amino acid substitutions, and 153 variant classification, we calculated the frequencies of distinct genomes deposited. Specifically, to 154 distinguish nucleotide polymorphisms at SARS-CoV-2 position 28916, we identified the number of 155 variations at the corresponding $215^{\text {th }}$ amino acid in the $\mathrm{N}$ protein. We determined nucleotide changes by 156 comparing the codon of the native glycine amino acid (28916-GGU-28918) to the codons of the variant

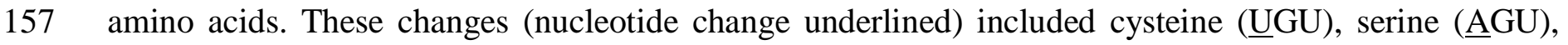
158 and arginine (CGU) amino acids. 
medRxiv preprint doi: https://doi.org/10.1101/2021.12.04.21267265; this version posted December 7, 2021. The copyright holder for this preprint (which was not certified by peer review) is the author/funder, who has granted medRxiv a license to display the preprint in perpetuity.

It is made available under a CC-BY-NC-ND 4.0 International license.

For statistical comparison of fraction of PBS with mismatches in genomes with detected targets

162 versus those with dropout, normality was assessed by D'Agostino and Pearson test (GraphPad Prism

163 v9.2.0). All distributions were non-parametric, and thus, a Mann-Whitney test (two-tailed) was

164 performed (GraphPad). To determine if specific mismatches were associated with specific target dropout

165 results, specimens were grouped by (1) presence or absence of the mismatch of interest (in the setting of

166 no other mismatches) and (2) detection or dropout of the target of interest - which resulted in a $2 \times 2$

167 contingency table which underwent association testing by Fisher's exact test. In addition to p-value,

168 relative risk $(\mathrm{RR})$ ratios and $95 \%$ confidence intervals $(\mathrm{CI})$ are provided for association testing.

169

170

Display Items

171

All figures are original and were generated using the GraphPad Prism software 9.2.0, Microsoft

172 Excel v16.54, and finished in Adobe Illustrator 2021 (v.25.4.1). Alignment plots were developed using

173 the package ggmsa (v.1.1.0) on $\mathrm{R}^{39}$ and finished in Adobe Illustrator. 
medRxiv preprint doi: https://doi.org/10.1101/2021.12.04.21267265; this version posted December 7, 2021. The copyright holder for this preprint (which was not certified by peer review) is the author/funder, who has granted medRxiv a license to display the preprint in perpetuity.

It is made available under a CC-BY-NC-ND 4.0 International license.

\section{Results}

Of 448 SARS-CoV-2-positive specimens, 117 (26\%) had all five targets detected with the remaining having one $(n=247)$ or more $(n=84)$ targets dropout. For the subset of 256 SARS-CoV-2positive specimens sequenced in our study, all five diagnostic targets were detected in 96 (38\%), with the remaining having one $(n=140)$ or more $(n=20)$ targets dropout (Table S2).

When we calculated weekly detection rates for individual targets among these SARS-CoV-2positive specimens, the N2 (0.61) and N3 (0.77) targets had the lowest average detection rates (Figure

1A). Notably, N2 and N3 detection rates were lowest at distinct periods of time. Among weeks with $\geq 3$ SARS-CoV-2-positive specimens sequenced, the N2 detection rate was lowest (0.13) in the week ending July 31, and the N3 detection rate was lowest (0.41) in the week ending May 1. We hypothesized this shift was due to changes in the population of circulating SARS-CoV-2 variants. When we compared individual target detection rates to reported prevalence of variants in NYC during the same time period, we found the $\mathrm{N} 3$ detection rate was lowest when the Alpha variant (B.1.1.7 + Q.x) was predominant at 33\% (Figure 1B). Similarly, the N2 detection rate was lowest when the Delta variant (B.1.617.2+ AY.x) comprised $96 \%$ of circulating SARS-CoV-2 in NYC. Given these findings, we used diagnostic target and paired genome sequence data to identify mismatches to Agena MassARRAY ${ }^{\circledR}$ target PBSs to determine impact of SARS-CoV-2 genomic diversity on diagnostic target performance.

\section{Impact of mismatches on target performance}

We aligned each diagnostic target PBS to each of the 256 SARS-CoV-2 genome sequences and calculated the number of mismatches to each target PBS for both detected and undetected targets (Figure 2). For four targets (N1, N3, ORF1A, ORF1AB), when the individual target was detected there was perfect complementarity ( 0 mismatches) between genome sequences and forward, reverse, and 
medRxiv preprint doi: https://doi.org/10.1101/2021.12.04.21267265; this version posted December 7, 2021. The copyright holder for this preprint (which was not certified by peer review) is the author/funder, who has granted medRxiv a license to display the preprint in perpetuity.

It is made available under a CC-BY-NC-ND 4.0 International license .

198 probe sequences for almost all (>99\%) specimens. However, for specimens in which the N2 target was

199 detected, mismatches occurred both at N2 forward (34.3\%) and reverse (46.6\%) PBSs (Figure 2B).

200 Specifically, among specimens with detectable N2 target, 1-3 mismatches to the forward PBS and up to 2011 mismatch to the reverse PBS were observed.

Notably, specimens with N2 target dropout had a significantly greater number of mismatches to

203 the N2 probe PBS (Figure 2B). The same was found for specimens with N3 dropout and mismatches to 204 the N3 forward PBS (Figure 2C). Of interest, more mismatches to the N2 reverse PBS were found for 205 specimens in which the N2 target was detected than for those with N2 dropout. Indeed, the majority of 206 specimens with detectable N2 target (85\%) harbored mismatches in N2 forward or reverse PBSs, but 0\% 207 of specimens with detectable N2 target harbored mismatches to the N2 probe PBS.

Site-specific polymorphisms affect target performance

Because mismatch position in PBSs can affect primer/probes binding to target sites ${ }^{40-43}$, we

211 characterized mismatch frequencies by position in each PBS (Figure 2). At least one mismatch was

212 identified in every target PBS with the exception of the N1 reverse, N3 reverse, and the ORF1AB

213 forward primers which had zero mismatches to all possible haplotypes in our dataset. To assess the level

214 of sequence diversity across each target, we calculated the nucleotide diversity per site $(\pi)$ for each PBS

215 sequence. Overall, genomes sequenced in this timeframe demonstrated the most diversity at N2 target

216 PBSs $(\geq 0.01260)$ followed by the N3 forward PBS (0.01075) (Figure 3B-C). Diversity at these targets

217 was at least seven-fold more than that at all other target PBSs. Notably, this diversity corresponded with

218 a predominance of Delta (56.7\%), Alpha (15.7\%), , and Iota (16.5\%) variant genomes in this dataset.

To identify individual mismatches associated with target dropout, we measured the proportion of

220 genomes with a mismatch at each PBS position and compared this level across specimens that yielded 
medRxiv preprint doi: https://doi.org/10.1101/2021.12.04.21267265; this version posted December 7, 2021. The copyright holder for this preprint (which was not certified by peer review) is the author/funder, who has granted medRxiv a license to display the preprint in perpetuity.

It is made available under a CC-BY-NC-ND 4.0 International license .

221 target detection or dropout (Figure S1). From 5' -to-3' direction, there were mismatches to $1^{\text {st }}-3^{\text {rd }}$ bp of 222 the N2 forward primer PBS (SARS-CoV-2 genome positions 28881 - 28883) in genomes that yielded 223 both N2 target detection and dropout (Figure 3B, Figure S1B). Overall, there were 192 specimens with 224 at least one mismatch to the first $3 \mathrm{bp}$ of the N2 forward primer. Of these, 49 (26\%) had a concurrent 225 trio of substitutions in the $N$ gene: G28881A, G28882A, and G28883C; the remaining 143 (74\%) 226 harbored a single G28881U substitution. The GGG-to-AAC and the G28881U substitutions were 227 independent of one another and no combinations of the two were detected. The majority of specimens with the trio (88\%) had detectable N2 target. In contrast, $78 \%$ of specimens with G28881U resulted in 229 dropout which - despite its position at the 5'-end of the N2 forward primer - represents a significant association of G28881U with N2 target dropout ( $\mathrm{p}<0.0001)$.

Interestingly, of 123 genomes with N2 target dropout we identified $111(90 \%)$ that harbored a mismatch at the terminal 3' base of the 22-bp-long N2 probe (Figure 3B, Figure S1B). All mismatches are the result of a guanine-to-uracil substitution in the $N$ gene (G28916U). This substitution was not identified among any of the 131 specimens with detectable N2 target. In fact, the relative risk of N2 target dropout in the setting of the G28916U substitution was 11.9-times greater than genomes with the native guanine $(\mathrm{p}<0.0001 ; 95 \% \mathrm{CI}$ : 8.17-14.06). We also determined that all 111 genomes with the G28916U substitution have the G28881U substitution. The linkage of the G28881U and G28916U 238 polymorphisms likely explains why the former - a 5'-end mismatch to the N2 forward PBS - is 239 associated with N2 target dropout. Indeed, $100 \%$ of genomes $(n=32)$ that possess the G28881U 240 substitution alone resulted in N2 target detection.

241 In the current study, of 36 specimens with N3 target dropout, 25 (69\%) had a mismatch at the 242 penultimate position of the 3'-end of the 20-bp-long N3 forward primer (Figure 3C, Figure S1C). This 243 mismatch corresponded with the adenine-to-uracil substitution in the ORF8 gene (A28095U) which 
medRxiv preprint doi: https://doi.org/10.1101/2021.12.04.21267265; this version posted December 7, 2021. The copyright holder for this preprint (which was not certified by peer review) is the author/funder, who has granted medRxiv a license to display the preprint in perpetuity.

It is made available under a CC-BY-NC-ND 4.0 International license .

causes a 20-fold risk of $\mathrm{N} 3$ target dropout relative to genomes with the native nucleotide $(\mathrm{p}<0.0001$;

95\% CI: 11.36-35.72) which is consistent with our findings earlier in the pandemic ${ }^{28}$, prior to the

current study period.

We assessed whether the associations between mismatch and corresponding target dropout

persist when quantity of virus genomic material in specimens is controlled as previously described ${ }^{28}$.

When analyses are limited to specimens for which all non-N2 targets are detected, the association of the

G28916U substitution with N2 dropout remains significant (p<0.0001; RR: 20.2; 95\% CI: 14.58-47.48).

In addition, when analyses are limited to specimens for which all non-N3 targets are detected, the

A28095U substitution remains significantly associated with N3 target dropout $(\mathrm{p}<0.0001 ; \mathrm{RR}$ : 31.03;

95\% CI: 10.95-91.10). These results indicate that the G28916U and A28095U substitutions are associated with N2 and N3 target dropout, respectively, independent of quantity of SARS-CoV-2.

\section{Lineage-specific variation and target dropout}

To determine whether target dropout was the result of lineage-specific variation, we examined phylogenetic lineages of genomes harboring the distinct polymorphisms. Among 25 specimens with N3 target dropout in this study, $23(92 \%)$ belonged to the B.1.1.7 lineage (Alpha variant) and 2 were partial genomes whose phylogenies could not be determined. These specimens were collected from April 11, 2021 (PV36791) through June 30, 2021 (PV37690), which mirrored the prevalence of the Alpha variant in NYC (Figure 1B).

264111 specimens that bore the G28916U polymorphism and resulted in N2 target dropout, the earliest was 265 from July 1, 2021 (PV37692) and the latest from August 21, 2021 (PV38720). All genomes 266 corresponded with lineages and sublineages of the Delta variant. Specifically, these included the 
medRxiv preprint doi: https://doi.org/10.1101/2021.12.04.21267265; this version posted December 7, 2021. The copyright holder for this preprint (which was not certified by peer review) is the author/funder, who has granted medRxiv a license to display the preprint in perpetuity.

It is made available under a CC-BY-NC-ND 4.0 International license .

B.1.617.2 $(n=67)$ lineage and AY.20 $(n=2)$, AY.23 $(n=1)$, AY.25 $(n=22)$, AY.3 $(n=17)$, AY.33 $(n=1)$, 268 and AY.5 (n=1) sublineages. We did not find the G28916U substitution among any of the other variant 269 lineages in our dataset (Figure 4A).

270 We broadened our analyses to interrogate SARS-CoV-2 genomes deposited globally for the 271 G28916U polymorphism. We utilized the publicly-available EpiCoV (GISAID) database and queried 272 2,103,844 sequences collected during the same timeframe of this study (Figure 4B). We found the Delta 273 variant (B.1.617.2 + AY.x) was predominant in the deposited genomes comprising $62 \%$ of all genomes $274(\mathrm{n}=1,313,492)$. The majority of these Delta genomes $(82 \%)$ harbored the G28916U substitution. Of the 275 remaining Delta genome sequences, almost all $(99.3 \%)$ had the native guanine nucleotide with a 276 minority of sequences $(<0.1 \%)$ harboring G28916A and G28916C substitutions. The G28916U 277 polymorphism - which results in the G215C amino acid substitution in the $\mathrm{N}$ protein - is almost 278 exclusive to Delta variant genomes but was rarely $(<0.02 \%)$ reported in other variant groups including 279 Alpha (B.1.1.7 + Q.x), Beta (B.1.351 + B.1.351.2 + B.1.351.3), Gamma (P.1 + P.1.x), Lambda (C.37 + 280 C.37.1), and $\mathrm{Mu}($ B.1.621 + B.1.621.1). 
medRxiv preprint doi: https://doi.org/10.1101/2021.12.04.21267265; this version posted December 7, 2021. The copyright holder for this preprint (which was not certified by peer review) is the author/funder, who has granted medRxiv a license to display the preprint in perpetuity.

It is made available under a CC-BY-NC-ND 4.0 International license .

\section{Discussion}

In the current study, we present a robust assessment of the impact of emergence of SARS-CoV-2 variants on detection of individual target genes included in the Agena MassARRAY ${ }^{\circledR}$ SARS-CoV-2 Panel, focusing on a five-month period characterized by rapid changes in circulating VOC and VOI. Molecular diagnostic tests to detect SARS-CoV-2, first designed almost two years ago, are challenged by continued viral circulation and rapid viral diversification, with continual emergence of new lineages. At the same time, recognition that some virus variants can demonstrate increased infectivity and disease severity among a broader population that now includes younger individuals 2,13,16,17,44 has raised awareness regarding assay sensitivity and risks for missed diagnoses. Although several studies have reported the impacts of viral sequence variation on conventional diagnostic platforms ${ }^{5,7,27,45}$ or have highlighted, in silico, potential interference of variant polymorphisms with publicly-available target sequences ${ }^{42,46,47}$, there are limited reports on assay performance in actu for detection of the Delta VOC and sublineages, and other recent VOC/VOI.

We utilized publicly-available primer/probe sequences of the Agena MassARRAY ${ }^{\circledR}$ SARS-CoV2 Panel and a deidentified dataset from clinical specimens that included individual target detection data and whole-genome sequencing to generate a snapshot of virus sequence diversity at each target PBS and to determine the extent to which polymorphisms are associated with individual target performance. Interestingly, we found that distinct viral substitutions resulted in N2 and N3 target dropout. Consistent with what we previously reported ${ }^{28}$, the A28095U substitution is a B.1.1.7-associated polymorphism that introduces a mismatch at the 3'-end of the N3 forward PBS which results in N3 target dropout. Notably, a marked change in the pattern of target dropout occurred during the course of the study with the introduction of the Delta VOC; we found the G28916U polymorphism unique to a subset of Delta variants results in a 3'-mismatch to the N2 probe and is associated with N2 dropout. Our findings 
medRxiv preprint doi: https://doi.org/10.1101/2021.12.04.21267265; this version posted December 7, 2021. The copyright holder for this preprint (which was not certified by peer review) is the author/funder, who has granted medRxiv a license to display the preprint in perpetuity.

It is made available under a CC-BY-NC-ND 4.0 International license .

highlight the robust capability of this multiple-target platform to capture diverse viral variants, as well as the ability of target performance to reflect lineage-specific sequence variation outside the conventional $S$ gene. emergent mutations to discern variant identity, particularly in the first months of 2021. Most panels utilize RT-PCR or novel isothermal technologies (e.g., RT-LAMP, CRISPR/Cas-based, massspectrometry) to target specific polymorphisms in the $S$ gene that have been ascribed to each of these

312 variants ${ }^{25,27,45,48-50}$. However, a recent deep analysis of circulating variants across the globe revealed 313 that most of these signature mutations are not under positive selection ${ }^{1}$. Therefore, other than a finite 314 number of mutations in the spike protein (e.g., N501Y, S477N, V1176F, N501Y), one can anticipate 315 that other variant-defining polymorphisms may not persist over continued circulation of SARS-CoV-2 and, thus, new target formulations will need to be continuously considered. As most efforts to accommodate new variants have been to redesign primers and probes or include more targets in this 318 region ${ }^{45,51}$, this may become impractical as inclusion of additional reactions can become costly and 319 introduce more room for error. Furthermore, although multiplexing assays allow for single-pot reactions, 320 the level of target redundancy is limited by the optical detection system as more fluorophores complicate 321 conventional diagnostic methods ${ }^{52-54}$. Therefore, as the COVID-19 pandemic continues and new 322 variants emerge, there can be great utility in existing assay platforms that target multiple regions outside 323 the $S$ gene.

Our findings also highlight the level of sequence diversity observed at each of these five target loci among sequences from VOC/VOI detected through August 2021. Among the Agena MassARRAY ${ }^{\circledR}$ SARS-CoV-2 Panel, $N$ gene targets (e.g., N2, N3) are challenged by the greatest level of nucleotide 327 diversity which can result in dropout of each. Consistent with phylogenetic analyses of global sequences 
medRxiv preprint doi: https://doi.org/10.1101/2021.12.04.21267265; this version posted December 7, 2021. The copyright holder for this preprint (which was not certified by peer review) is the author/funder, who has granted medRxiv a license to display the preprint in perpetuity.

It is made available under a CC-BY-NC-ND 4.0 International license .

$32{ }^{1}$, the N2 target region has the greatest sequence diversity. Although, a number of polymorphisms in the

$329 N$ gene are under positive selection ${ }^{1,46,55}$, the evolutionary pressures exerted on A28095U (ORF8|K68*)

330 and G28916U (N|G215C) polymorphisms have not demonstrated positive selection or purported 331 epistatic interactions ${ }^{1,16}$. This is likely due to the earlier timeframes for which each of these 332 phylogenetic studies were performed (e.g., December 2020 through May 2021) and the lack of robust

333 functional genomic studies in SARS-CoV-2. Thus, the fate of each of these polymorphisms is unclear 334 among emergent VOC, and each should be taken into consideration for use of this diagnostic platform 335 and others that target the same $N$ gene regions going forward.

As SARS-CoV-2 variants continue to arise, robust platforms with high target redundancy for

337 virus detection and diagnosis are vital to capture new or existing lineages. As contemporary 338 polymorphisms undergo selection, evaluation of diagnostic target performance in the clinical setting can 339 help elucidate ongoing viral dynamics in patient communities and highlight platform target 340 combinations that should be further optimized. Lastly, our results reinforce the need for continuing 341 surveillance of assay target result patterns to increase the sensitivity of current molecular tests for 342 SARS-CoV-2 detection and to assure the adequate diagnosis of COVID-19 worldwide. 
medRxiv preprint doi: https://doi.org/10.1101/2021.12.04.21267265; this version posted December 7, 2021. The copyright holder for this preprint (which was not certified by peer review) is the author/funder, who has granted medRxiv a license to display the preprint in perpetuity. It is made available under a CC-BY-NC-ND 4.0 International license.

\section{Code availability}

345 To generate genome sequences, sequencing data were analyzed using a custom reference-based

346 (MN908947.3) pipeline, https://github.com/mjsull/COVID_pipe ${ }^{56}$. To analyze mismatches to diagnostic

347 target PBSs, genome sequences were processed using a custom Unix-code

348 https://github.com/AceM1188/SACOV_primer-probe_analyses ${ }^{38}$.

350 Data availability

351 SARS-CoV-2 sequencing read data for all study genomes were deposited in GISAID [www.gisaid.org] 352 (accessions pending). 
medRxiv preprint doi: https://doi.org/10.1101/2021.12.04.21267265; this version posted December 7, 2021. The copyright holder for this preprint (which was not certified by peer review) is the author/funder, who has granted medRxiv a license to display the preprint in perpetuity. It is made available under a CC-BY-NC-ND 4.0 International license .

\section{References}

1. Rochman ND, Wolf YI, Faure G, Mutz P, Zhang F, Koonin EV. Ongoing global and regional adaptive evolution of SARS-CoV-2. Proc Natl Acad Sci U S A, 2021, 118

2. Tao K, Tzou PL, Nouhin J, Gupta RK, de Oliveira T, Kosakovsky Pond SL, Fera D, Shafer RW. The biological and clinical significance of emerging SARS-CoV-2 variants. Nat Rev Genet, 2021, 22:757-73

3. Artesi M, Bontems S, Göbbels P, Franckh M, Maes P, Boreux R, Meex C, Melin P, Hayette M-P, Bours V, Durkin K. A Recurrent Mutation at Position 26340 of SARS-CoV-2 Is Associated with Failure of the E Gene Quantitative Reverse Transcription-PCR Utilized in a Commercial DualTarget Diagnostic Assay. J Clin Microbiol, 2020, 58

4. Rana DR, Pokhrel N. Sequence mismatch in PCR probes may mask the COVID-19 detection in Nepal. Mol Cell Probes, 2020, 53:101599

5. Bal A, Destras G, Gaymard A, Stefic K, Marlet J, Eymieux S, Regue H, Semanas Q, d'Aubarede C, Billaud G, Laurent F, Gonzalez C, Mekki Y, Valette M, Bouscambert M, Gaudy-Graffin C, Lina B, Morfin F, Josset L, COVID-Diagnosis HCL Study Group. Two-step strategy for the identification of SARS-CoV-2 variant of concern 202012/01 and other variants with spike deletion H69-V70, France, August to December 2020. Euro Surveill, 2021, 26

6. Tahan S, Parikh BA, Droit L, Wallace MA, Burnham CA, Wang D. SARS-CoV-2 E gene variant alters analytical sensitivity characteristics of viral detection using a commercial RT-PCR assay. J Clin Microbiol, 2021. https://doi.org/10.1128/JCM.00075-21

7. Brown KA, Gubbay J, Hopkins J, Patel S, Buchan SA, Daneman N, Goneau LW. S-Gene Target Failure as a Marker of Variant B.1.1.7 Among SARS-CoV-2 Isolates in the Greater Toronto Area, December 2020 to March 2021. JAMA, 2021, 325:2115-6

8. Braybrook E, Pandey S, Vryonis E, Anderson NR, Young L, Grammatopoulos D. Screening for the alpha variant of SARS-CoV-2 (B.1.1.7) and the impact of this variant on circulating biomarkers in hospitalised patients. BioRxiv, 2021. https://doi.org/10.1101/2021.06.18.21258699

9. Sánchez-Calvo JM, Alados Arboledas JC, Ros Vidal L, de Francisco JL, López Prieto MD. Diagnostic pre-screening method based on N-gene dropout or delay to increase feasibility of SARS-CoV-2 VOC B.1.1.7 detection. Diagn Microbiol Infect Dis, 2021, 101:115491

10. Centers for Disease Control and Prevention, US Department of Health and Human Services. CDC COVID Data Tracker, n.d. https://covid.cdc.gov/covid-data-tracker/\#variant-proportions. (accessed July 4, 2021)

11. The Delta Variant: What Scientists Know. The New York Times, 2021. https://www.nytimes.com/2021/06/22/health/delta-variant-covid.html. (accessed July 4, 2021)

12. Dhar MS, Marwal R, Radhakrishnan VS, Ponnusamy K, Jolly B, Bhoyar RC, Sardana V, Naushin S, Rophina M, Mellan TA, Mishra S, Whittaker C, Fatihi S, Datta M, Singh P, Sharma U, Ujjainiya R, Batheja N, Divakar MK, Singh MK, Imran M, Senthivel V, Maurya R, Jha N, Mehta P, Vivekanand A, Sharma P, Arvinden VR, Chaudhary U, Soni N, Thukral L, Flaxman S, Bhatt S, Pandey R, Dash D, et al. Genomic characterization and Epidemiology of an emerging SARS-CoV2 variant in Delhi, India. MedRxiv, 2021:2021.06.02.21258076

13. Malden DE, Bruxvoort KJ, Tseng HF, Ackerson B, Choi SK, Florea A, Tubert J, Takhar H, Aragones M, Hong V, Talarico CA, McLaughlin JM, Qian L, Tartof SY. Distribution of SARSCoV-2 Variants in a Large Integrated Health Care System - California, March-July 2021. MMWR Morb Mortal Wkly Rep, 2021, 70:1415-9 
medRxiv preprint doi: https://doi.org/10.1101/2021.12.04.21267265; this version posted December 7, 2021. The copyright holder for this preprint (which was not certified by peer review) is the author/funder, who has granted medRxiv a license to display the preprint in perpetuity. It is made available under a CC-BY-NC-ND 4.0 International license .

14. New York City Department of Health. COVID-19: Data. NYC Health COVID-19: Data on Variants, n.d. https://www1.nyc.gov/site/doh/covid/covid-19-data-variants.page. (accessed July 4, 2021)

15. The Pango Lineage Nomenclature. Pango Network. PangoNetwork, 2021. https://www.pango.network/new-ay-lineages/. (accessed November 29, 2021)

16. Elliott P, Haw D, Wang H, Eales O, Walters CE, Ainslie KEC, Atchison C, Fronterre C, Diggle PJ, Page AJ, Trotter AJ, Prosolek SJ, COVID-19 Genomics UK (COG-UK) Consortium11 Donnelly CA, Barclay W, Taylor G, Cooke G, Ward H, Darzi A, Riley S, Robson SC, Loman NJ, Connor TR, Golubchik T, Martinez Nunez RT, Ludden C, Corden S, Johnston I, Bonsall D, Smith CP, Awan AR, Bucca G, Torok ME, Saeed K, et al. Exponential growth, high prevalence of SARSCoV-2, and vaccine effectiveness associated with the Delta variant. Science, 2021:eab19551

17. Embi PJ, Levy ME, Naleway AL, Patel P, Gaglani M, Natarajan K, Dascomb K, Ong TC, Klein NP, Liao I-C, Grannis SJ, Han J, Stenehjem E, Dunne MM, Lewis N, Irving SA, Rao S, McEvoy C, Bozio CH, Murthy K, Dixon BE, Grisel N, Yang D-H, Goddard K, Kharbanda AB, Reynolds S, Raiyani C, Fadel WF, Arndorfer J, Rowley EA, Fireman B, Ferdinands J, Valvi NR, Ball SW, Zerbo O, et al. Effectiveness of 2-Dose Vaccination with mRNA COVID-19 Vaccines Against COVID-19-Associated Hospitalizations Among Immunocompromised Adults - Nine States, January-September 2021. MMWR Morb Mortal Wkly Rep, 2021, 70:1553-9

18. Tenforde MW, Self WH, Adams K, Gaglani M, Ginde AA, McNeal T, Ghamande S, Douin DJ, Talbot HK, Casey JD, Mohr NM, Zepeski A, Shapiro NI, Gibbs KW, Files DC, Hager DN, Shehu A, Prekker ME, Erickson HL, Exline MC, Gong MN, Mohamed A, Henning DJ, Steingrub JS, Peltan ID, Brown SM, Martin ET, Monto AS, Khan A, Hough CL, Busse LW, Ten Lohuis CC, Duggal A, Wilson JG, Gordon AJ, et al. Association Between mRNA Vaccination and COVID-19 Hospitalization and Disease Severity. JAMA, 2021. https://doi.org/10.1001/jama.2021.19499

19. Liu C, Ginn HM, Dejnirattisai W, Supasa P, Wang B, Tuekprakhon A, Nutalai R, Zhou D, Mentzer AJ, Zhao Y, Duyvesteyn HME, López-Camacho C, Slon-Campos J, Walter TS, Skelly D, Johnson SA, Ritter TG, Mason C, Costa Clemens SA, Gomes Naveca F, Nascimento V, Nascimento F, Fernandes da Costa C, Resende PC, Pauvolid-Correa A, Siqueira MM, Dold C, Temperton N, Dong T, Pollard AJ, Knight JC, Crook D, Lambe T, Clutterbuck E, Bibi S, et al. Reduced neutralization of SARS-CoV-2 B.1.617 by vaccine and convalescent serum. Cell, 2021, 184:42204236.e13

20. Planas D, Veyer D, Baidaliuk A, Staropoli I, Guivel-Benhassine F, Rajah MM, Planchais C, Porrot F, Robillard N, Puech J, Prot M, Gallais F, Gantner P, Velay A, Le Guen J, Kassis-Chikhani N, Edriss D, Belec L, Seve A, Courtellemont L, Péré H, Hocqueloux L, Fafi-Kremer S, Prazuck T, Mouquet H, Bruel T, Simon-Lorière E, Rey FA, Schwartz O. Reduced sensitivity of SARS-CoV-2 variant Delta to antibody neutralization. Nature, 2021, 596:276-80

21. Bolze A, Cirulli ET, Luo S, White S, Wyman D, Rossi AD, Machado H, Cassens T, Jacobs S, Schiabor Barrett KM, Tsan K, Nguyen J, Ramirez JM, Sandoval E, Wang X, Wong D, Becker D, Laurent M, Lu JT, Isaksson M, Washington NL, Lee W. SARS-CoV-2 variant Delta rapidly displaced variant Alpha in the United States and led to higher viral loads. MedRxiv, 2021:2021.06.20.21259195

22. Challen R, Dyson L, Overton CE, Guzman-Rincon LM, Hill EM, Stage HB, Brooks-Pollock E, Pellis L, Scarabel F, Pascall DJ, Blomquist P, Tildesley M, Williamson D, Siegert S, Xiong X, Youngman B, Read JM, Gog JR, Keeling MJ, Danon L, Juniper. Early epidemiological signatures of novel SARS-CoV-2 variants: establishment of B.1.617.2 in England. BioRxiv, 2021. https://doi.org/10.1101/2021.06.05.21258365 
medRxiv preprint doi: https://doi.org/10.1101/2021.12.04.21267265; this version posted December 7, 2021. The copyright holder for this preprint (which was not certified by peer review) is the author/funder, who has granted medRxiv a license to display the preprint in perpetuity. It is made available under a CC-BY-NC-ND 4.0 International license .

23. Lopez Bernal J, Andrews N, Gower C, Gallagher E, Simmons R, Thelwall S, Stowe J, Tessier E, Groves N, Dabrera G, Myers R, Campbell CNJ, Amirthalingam G, Edmunds M, Zambon M, Brown KE, Hopkins S, Chand M, Ramsay M. Effectiveness of Covid-19 Vaccines against the B.1.617.2 (Delta) Variant. N Engl J Med, 2021, 385:585-94

24. Tang P, Hasan MR, Chemaitelly H, Yassine HM, Benslimane FM, Al Khatib HA, AlMukdad S, Coyle P, Ayoub HH, Al Kanaani Z, Al Kuwari E, Jeremijenko A, Kaleeckal AH, Latif AN, Shaik RM, Abdul Rahim HF, Nasrallah GK, Al Kuwari MG, Al Romaihi HE, Butt AA, Al-Thani MH, Al Khal A, Bertollini R, Abu-Raddad LJ. BNT162b2 and mRNA-1273 COVID-19 vaccine effectiveness against the SARS-CoV-2 Delta variant in Qatar. Nat Med, 2021. https://doi.org/10.1038/s41591-021-01583-4

25. Zhao F, Lu J, Lu B, Qin T, Wang X, Hou X, Meng F, Xu X, Li T, Zhou H, Zhang J, Kan B, Huang Y, Zhang Z, Xiao D. A Novel Strategy for the Detection of SARS-CoV-2 Variants Based on Multiplex PCR-Mass Spectrometry Minisequencing Technology. Microbiol Spectr, 2021:e0126721

26. So M-K, Park S, Lee K, Kim S-K, Chung H-S, Lee M. Variant Prediction by Analyzing RdRp/S Gene Double or Low Amplification Pattern in Allplex SARS-CoV-2 Assay. Diagnostics (Basel), 2021, 11

27. Buchta C, Camp JV, Jovanovic J, Radler U, Benka B, Puchhammer-Stöckl E, Müller MM, Griesmacher A, Aberle SW, Görzer I. Inadequate design of mutation detection panels prevents interpretation of variants of concern: results of an external quality assessment for SARS-CoV-2 variant detection. Clin Chem Lab Med, 2021. https://doi.org/10.1515/cclm-2021-0889

28. Hernandez MM, Banu R, Gonzalez-Reiche AS, van de Guchte A, Khan Z, Shrestha P, Cao L, Chen F, Shi H, Hanna A, Alshammary H, Fabre S, Amoako A, Obla A, Alburquerque B, Helena Patiño L, Ramírez JD, Sebra R, Gitman MR, Nowak MD, Cordon-Cardo C, Schutzbank TE, Simon V, van Bakel H, Sordillo EM, Paniz-Mondolfi AE. Robust clinical detection of SARS-CoV-2 variants by RT-PCR/MALDI-TOF multi-target approach. BioRxiv, 2021. https://doi.org/10.1101/2021.09.09.21263348

29. Gonzalez-Reiche AS, Hernandez MM, Sullivan MJ, Ciferri B, Alshammary H, Obla A, Fabre S, Kleiner G, Polanco J, Khan Z, Alburquerque B, van de Guchte A, Dutta J, Francoeur N, Melo BS, Oussenko I, Deikus G, Soto J, Sridhar SH, Wang Y-C, Twyman K, Kasarskis A, Altman DR, Smith M, Sebra R, Aberg J, Krammer F, García-Sastre A, Luksza M, Patel G, Paniz-Mondolfi A, Gitman M, Sordillo EM, Simon V, van Bakel H. Introductions and early spread of SARS-CoV-2 in the New York City area. Science, 2020, 369:297-301

30. Hernandez MM, Gonzalez-Reiche AS, Alshammary H, Fabre S, Khan Z, van De Guchte A, Obla A, Ellis E, Sullivan MJ, Tan J, Alburquerque B, Soto J, Wang C-Y, Sridhar SH, Wang Y-C, Smith M, Sebra R, Paniz-Mondolfi AE, Gitman MR, Nowak MD, Cordon-Cardo C, Luksza M, Krammer F, van Bakel H, Simon V, Sordillo EM. Molecular evidence of SARS-CoV-2 in New York before the first pandemic wave. Nat Commun, 2021, 12:3463

31. Hernandez MM, Banu R, Shrestha P, Patel A, Chen F, Cao L, Fabre S, Tan J, Lopez H, Chiu N, Shifrin B, Zapolskaya I, Flores V, Lee PY, Castañeda S, Ramírez JD, Jhang J, Osorio G, Gitman MR, Nowak MD, Reich DL, Cordon-Cardo C, Sordillo EM, Paniz-Mondolfi AE. RTPCR/MALDI-TOF mass spectrometry-based detection of SARS-CoV-2 in saliva specimens. J Med Virol, 2021. https://doi.org/10.1002/jmv.27069

32. Rambaut A, Holmes EC, O'Toole Á, Hill V, McCrone JT, Ruis C, du Plessis L, Pybus OG. A dynamic nomenclature proposal for SARS-CoV-2 lineages to assist genomic epidemiology. Nat Microbiol, 2020, 5:1403-7 
medRxiv preprint doi: https://doi.org/10.1101/2021.12.04.21267265; this version posted December 7, 2021. The copyright holder for this preprint (which was not certified by peer review) is the author/funder, who has granted medRxiv a license to display the preprint in perpetuity. It is made available under a CC-BY-NC-ND 4.0 International license .

33. O’Toole Á, Scher E, Underwood A, Jackson B, Hill V, McCrone JT, Ruis C, Abu-Dahab K, Taylor B, Yeats C, du Plessis L, Aanensen D, Holmes E, Pybus O, Rambaut A. pangolin: lineage assignment in an emerging pandemic as an epidemiological tool. Github, n.d. https://github.com/cov-lineages/pangolin

34. Agena Bioscience, Inc. MassARRAY® SARS-CoV-2 Panel Instructions for Use. 2021

35. Katoh K, Misawa K, Kuma K-I, Miyata T. MAFFT: a novel method for rapid multiple sequence alignment based on fast Fourier transform. Nucleic Acids Res, 2002, 30:3059-66

36. Hu T, Li J, Zhou H, Li C, Holmes EC, Shi W. Bioinformatics resources for SARS-CoV-2 discovery and surveillance. Brief Bioinform, 2021, 22:631-41

37. Pfeifer B, Wittelsbürger U, Ramos-Onsins SE, Lercher MJ. PopGenome: an efficient Swiss army knife for population genomic analyses in R. Mol Biol Evol, 2014, 31:1929-36

38. Hernandez (AceM1188) MM. AceM1188/SACOV_primer-probe_analyses. Zenodo, 2021. https://10.5281/zenodo.4920818. (accessed June 9, 2021)

39. Zhou L, Yu G. ggmsa: Plot Multiple Sequence Alignment using “ggplot2,” 2021

40. Kwok S, Kellogg DE, McKinney N, Spasic D, Goda L, Levenson C, Sninsky JJ. Effects of primertemplate mismatches on the polymerase chain reaction: human immunodeficiency virus type 1 model studies. Nucleic Acids Res, 1990, 18:999-1005

41. Lefever S, Pattyn F, Hellemans J, Vandesompele J. Single-nucleotide polymorphisms and other mismatches reduce performance of quantitative PCR assays. Clin Chem, 2013, 59:1470-80

42. Wang R, Hozumi Y, Yin C, Wei G-W. Mutations on COVID-19 diagnostic targets. Genomics, 2020, 112:5204-13

43. Whiley DM, Sloots TP. Sequence variation in primer targets affects the accuracy of viral quantitative PCR. J Clin Virol, 2005, 34:104-7

44. Delahoy MJ, Ujamaa D, Whitaker M, O’Halloran A, Anglin O, Burns E, Cummings C, Holstein R, Kambhampati AK, Milucky J, Patel K, Pham H, Taylor CA, Chai SJ, Reingold A, Alden NB, Kawasaki B, Meek J, Yousey-Hindes K, Anderson EJ, Openo KP, Teno K, Weigel A, Kim S, Leegwater L, Bye E, Como-Sabetti K, Ropp S, Rudin D, Muse A, Spina N, Bennett NM, Popham K, Billing LM, Shiltz E, et al. Hospitalizations Associated with COVID-19 Among Children and Adolescents - COVID-NET, 14 States, March 1, 2020-August 14, 2021. MMWR Morb Mortal Wkly Rep, 2021, 70:1255-60

45. Nörz D, Pfefferle S, Grunwald M, Fischer N, Aepfelbacher M, Lütgehetmann M. Modifying a Diagnostic SARS-CoV-2 Spike PCR to Turn a De169/70 Dropout into a Discriminatory On-Target Assay. J Mol Diagn, 2021, 23:777-8

46. Jaroszewski L, Iyer M, Alisoltani A, Sedova M, Godzik A. The interplay of SARS-CoV-2 evolution and constraints imposed by the structure and functionality of its proteins. PLoS Comput Biol, 2021, 17:e1009147

47. Gand M, Vanneste K, Thomas I, Van Gucht S, Capron A, Herman P, Roosens NHC, De Keersmaecker SCJ. Deepening of In Silico Evaluation of SARS-CoV-2 Detection RT-qPCR Assays in the Context of New Variants. Genes , 2021, 12

48. Kline EC, Panpradist N, Hull IT, Wang Q, Oreskovic AK, Han PD, Starita LM, Lutz BR. Multiplex Target-Redundant RT-LAMP for Robust Detection of SARS-CoV-2 Using Fluorescent Universal Displacement Probes. MedRxiv, 2021. https://doi.org/10.1101/2021.08.13.21261995

49. Jamwal VL, Kumar N, Bhat R, Jamwal PS, Singh K, Dogra S, Kulkarni A, Bhadra B, Shukla MR, Saran S, Dasgupta S, Vishwakarma RA, Gandhi SG. Optimization and validation of RT-LAMP assay for diagnosis of SARS-CoV2 including the globally dominant Delta variant. Virol J, 2021, 18:178 
medRxiv preprint doi: https://doi.org/10.1101/2021.12.04.21267265; this version posted December 7, 2021. The copyright holder for this preprint (which was not certified by peer review) is the author/funder, who has granted medRxiv a license to display the preprint in perpetuity. It is made available under a CC-BY-NC-ND 4.0 International license .

50. Arizti-Sanz J, Bradley AD, Zhang YB, Boehm CK, Freije CA, Grunberg ME, Kosoko-Thoroddsen T-SF, Welch NL, Pillai PP, Mantena S, Kim G, Uwanibe JN, John OG, Eromon PE, Kocher G, Gross R, Lee JS, Hensley LE, Happi CT, Johnson J, Sabeti PC, Myhrvold C. Equipment-free detection of SARS-CoV-2 and Variants of Concern using Cas13. MedRxiv, 2021. https://doi.org/10.1101/2021.11.01.21265764

51. Chaintoutis SC, Chassalevris T, Balaska S, Mouchtaropoulou E, Tsiolas G, Vlatakis I, Tychala A, Koutsioulis D, Argiriou A, Skoura L, Dovas CI. A Novel Real-Time RT-PCR-Based Methodology for the Preliminary Typing of SARS-CoV-2 Variants, Employing Non-Extendable LNA Oligonucleotides and Three Signature Mutations at the Spike Protein Receptor-Binding Domain. Life, 2021, 11

52. Ahberg CD, Manz A, Neuzil P. Single Fluorescence Channel-based Multiplex Detection of Avian Influenza Virus by Quantitative PCR with Intercalating Dye. Sci Rep, 2015, 5:11479

53. Zhang H, Gaňová M, Yan Z, Chang H, Neužil P. PCR Multiplexing Based on a Single Fluorescent Channel Using Dynamic Melting Curve Analysis. ACS Omega, 2020, 5:30267-73

54. Zhang H, Yan Z, Wang X, Gaňová M, Chang H, Laššáková S, Korabecna M, Neuzil P. Determination of Advantages and Limitations of qPCR Duplexing in a Single Fluorescent Channel. ACS Omega, 2021, 6:22292-300

55. Martin DP, Weaver S, Tegally H, San EJ, Shank SD, Wilkinson E, Lucaci AG, Giandhari J, Naidoo S, Pillay Y, Singh L, Lessells RJ, NGS-SA, COVID-19 Genomics UK (COG-UK), Gupta RK, Wertheim JO, Nekturenko A, Murrell B, Harkins GW, Lemey P, MacLean OA, Robertson DL, de Oliveira T, Kosakovsky Pond SL. The emergence and ongoing convergent evolution of the N501Y lineages coincides with a major global shift in the SARS-CoV-2 selective landscape. MedRxiv, 2021. https://doi.org/10.1101/2021.02.23.21252268

56. mjsull. mjsull/COVID_pipe: initial release (Version v0.1.0). Zenodo, 2020, April 29. http://doi.org/10.5281/zenodo.3775031 
medRxiv preprint doi: https://doi.org/10.1101/2021.12.04.21267265; this version posted December 7, 2021. The copyright holder for this preprint (which was not certified by peer review) is the author/funder, who has granted medRxiv a license to display the preprint in perpetuity.

It is made available under a CC-BY-NC-ND 4.0 International license.

\section{Acknowledgments}

561 We thank the members of MSHS MML, Simon, and van Bakel laboratories for providing any assistance

562 when needed throughout this study. We are grateful for the continuous expert guidance provided by the 563 ISMMS Program for the Protection of Human Subjects (PPHS).

564 We are thankful for the efforts of the Mount Sinai Pathogen Surveillance Program (PSP) Study Group 565 members: Hala Alshammary, Angela A. Amoako, Jose Polanco, Aria Rooker, Christian Cognigni, 566 Mahmoud H. Awawda, Ashley-Beathrese T. Salimbangon, Zenab Khan, and Zain Khalil.

567 The Research reported in this paper was supported by the National Institutes of Health (NIH) contract 568 number HHSN272201400008C, the NIH Office of Research Infrastructure under award numbers 569 S10OD018522 and S10OD026880, institutional and philanthropic funds (Open Philanthropy Project, 570 \#2020-215611), as well as a Robin Chemers Neustein Postdoctoral Fellowship Award (to Dr. Gonzalez$571 \quad$ Reiche).

\section{Author contributions}

574 M.M.H., R.B., P.S., A.E.PM., M.R.G., M.D.N., and E.M.S. provided clinical samples for the study. 575 M.M.H., R.B., B.G., P.S., L.C., F.C., H.S., A.H., M.S.PSP.S.G. and A.E.PM. accessioned clinical 576 samples. A.S.GR., A.v.d.G, M.S.PSP.S.G., and H.v.B. performed NGS experiments. R.S. provided NGS 577 services. A.S.GR. performed genome assembly, data curation and genotyping. M.M.H performed 578 alignments and mismatch analyses. M.M.H., R.B., J.D.R., M.R.G., M.D.N., C.C.C., T.E.S., V.S., 579 H.v.B., E.M.S., and A.E.PM analyzed, interpreted, or discussed data. M.M.H., E.M.S., and A.E.PM. 580 wrote the manuscript. M.M.H., E.M.S., and A.E.PM. conceived the study. E.M.S. and A.E.PM. 581 supervised the study. H.v.B., V.S., and E.M.S. raised financial support. 
medRxiv preprint doi: https://doi.org/10.1101/2021.12.04.21267265; this version posted December 7, 2021. The copyright holder for this preprint (which was not certified by peer review) is the author/funder, who has granted medRxiv a license to display the preprint in perpetuity. It is made available under a CC-BY-NC-ND 4.0 International license.

582 M.M.H. and A.E.PM are the guarantors of this work and, as such, had full access to all of the data in the 583 study and take responsibility for the integrity of the data and the accuracy of the data analysis. 
medRxiv preprint doi: https://doi.org/10.1101/2021.12.04.21267265; this version posted December 7, 2021. The copyright holder for this preprint (which was not certified by peer review) is the author/funder, who has granted medRxiv a license to display the preprint in perpetuity. It is made available under a CC-BY-NC-ND 4.0 International license.

\section{Competing Interests}

585 Robert Sebra is VP of Technology Development and a stockholder at Sema4, a Mount Sinai Venture.

586 This work, however, was conducted solely at Icahn School of Medicine at Mount Sinai. Otherwise, the 587 authors declare no competing interests. 
medRxiv preprint doi: https://doi.org/10.1101/2021.12.04.21267265; this version posted December 7, 2021. The copyright holder for this preprint (which was not certified by peer review) is the author/funder, who has granted medRxiv a license to display the preprint in perpetuity. It is made available under a CC-BY-NC-ND 4.0 International license.

\section{$589 \quad$ Figure Legends}

590 Figure 1. RT-PCR/MALDI-TOF target detection rate in SARS-CoV-2-positive specimens. (A)

591 Heatmap depicting the proportion of SARS-CoV-2-positive specimens that have detectable RT-

592 PCR/MALDI-TOF targets (N1, N2, N3, ORF1A, ORF1AB) by week from April 11 through August 28, 593 2021. The total number of SARS-CoV-2-positive specimens and the number of SARS-CoV-2-positive 594 specimens sequenced by pathogen surveillance are depicted above each week (column). Grey boxes 595 indicate weeks where no specimens were positive for SARS-CoV-2 on this platform. (B) Stacked area 596 plots depicting frequencies of SARS-CoV-2 variants reported by publicly-available NYC Department of 597 Health surveillance data within the same timeframe. 
medRxiv preprint doi: https://doi.org/10.1101/2021.12.04.21267265; this version posted December 7, 2021. The copyright holder for this preprint (which was not certified by peer review) is the author/funder, who has granted medRxiv a license to display the preprint in perpetuity.

It is made available under a CC-BY-NC-ND 4.0 International license.

\section{Figure 2. Frequencies of target PBS mismatches and RT-PCR/MALDI-TOF target detection}

600 results. Number of mismatches normalized to the number of nucleotides in primer/probe binding sites

601 (PBS length) across five diagnostic targets: (A) N1, (B) N2, (C) N3, (D) ORF1A, (E) ORF1AB. Each

602 point represents the calculated mismatches per specimen consensus genome for each target PBS. Violin

603 plots represent the distribution as density of the points grouped by primer/probe sequence (forward

604 (For), reverse (Rev), Probe) and by target detection result (detected (magenta), dropout (turquoise)).

605 Numbers of genomes analyzed for mismatches are depicted above each violin plot. Medians (yellow

606 lines) are depicted and bars above distributions represent statistical comparisons (Mann-Whitney test; *,

$607 \mathrm{P}<0.05 ; * * * *, \mathrm{P}<0.0001)$.

608 
medRxiv preprint doi: https://doi.org/10.1101/2021.12.04.21267265; this version posted December 7, 2021. The copyright holder for this preprint (which was not certified by peer review) is the author/funder, who has granted medRxiv a license to display the preprint in perpetuity.

It is made available under a CC-BY-NC-ND 4.0 International license .

609 Figure 3. Alignment of SARS-CoV-2 haplotypes to RT-PCR/MALDI-TOF targets. Multiple

610 sequence alignment of haplotype sequences to forward, reverse, and probe binding sites for (A) N1, (B)

$611 \mathrm{~N} 2,(\mathrm{C}) \mathrm{N} 3,(\mathrm{D})$ ORF1A, and (E) ORF1AB targets. In each alignment, the reference sequence

612 (NC_045512.2) is annotated above comprised of color-coded nucleotides. The coordinates of the

613 reference sequence are annotated at the bottom corners of each alignment. Each row represents a

614 haplotype sequence that aligns to the target site. Absolute counts of each haplotype (e.g., Hap_1, Hap_2,

615 etc.) within the dataset and counts stratified by variant lineage (e.g., Alpha, Delta, Iota) are depicted to

616 the right side of each haplotype sequence. Positions of primer/probe sequences are indicated by arrows

617 where tail to arrowhead reflects 5' to 3' directionality. Grey boxes with black dotted borders outline

618 PBSs. Dots represent conserved nucleotides at each position and mismatched nucleotides are indicated.

619 PBS mismatches are indicated by arrows; red arrows reflect mismatches that are significantly associated

620 with target dropout. Notably, the association of the G28881U mismatch to the N2 forward PBS (panel

621 C, red "(U)") with target dropout is distinguished from the G28881A mismatch. Nucleotide diversity $(\pi)$

622 of sequences at each PBS is indicated.

623 
medRxiv preprint doi: https://doi.org/10.1101/2021.12.04.21267265; this version posted December 7, 2021. The copyright holder for this preprint

(which was not certified by peer review) is the author/funder, who has granted medRxiv a license to display the preprint in perpetuity.

It is made available under a CC-BY-NC-ND 4.0 International license .

624 Figure 4. Delta-specific substitution interferes with N2 diagnostic target detection. (A) Stacked bar

625 plots depict the composition of SARS-CoV-2 variants in 254 MSHS genomes tested by RT-

626 PCR/MALDI-TOF. Bar plots reflect absolute number of genomes with N2 target dropout (left) and

627 those with N2 target detection (right). Variant groups are color-coded and genomes with the G28916U

628 polymorphism are depicted by a hatched pattern. (B) Stacked bar plot of publicly-available sequences

629 (GISAID, see methods) from the same timeframe of this study depicting absolute numbers of variant

630 genomes and presence or absence of the G28916U polymorphism. Color-coding and patterns are the

631 same as in (A).

632 
A

\section{Target detection rate in SARS-CoV-2-positive specimens}

$\begin{array}{lllllllllllllllllllll}\text { No. Positive } & 63 & 18 & 20 & 23 & 30 & 10 & 7 & 1 & 0 & 4 & 0 & 3 & 6 & 5 & 7 & 18 & 30 & 83 & 107 & 13\end{array}$

$\begin{array}{lllllllllllllllllllll}\text { No. Sequenced } & 45 & 14 & 17 & 15 & 12 & 4 & 2 & 1 & 0 & 4 & 0 & 3 & 3 & 2 & 2 & 8 & 16 & 47 & 62 & 3\end{array}$

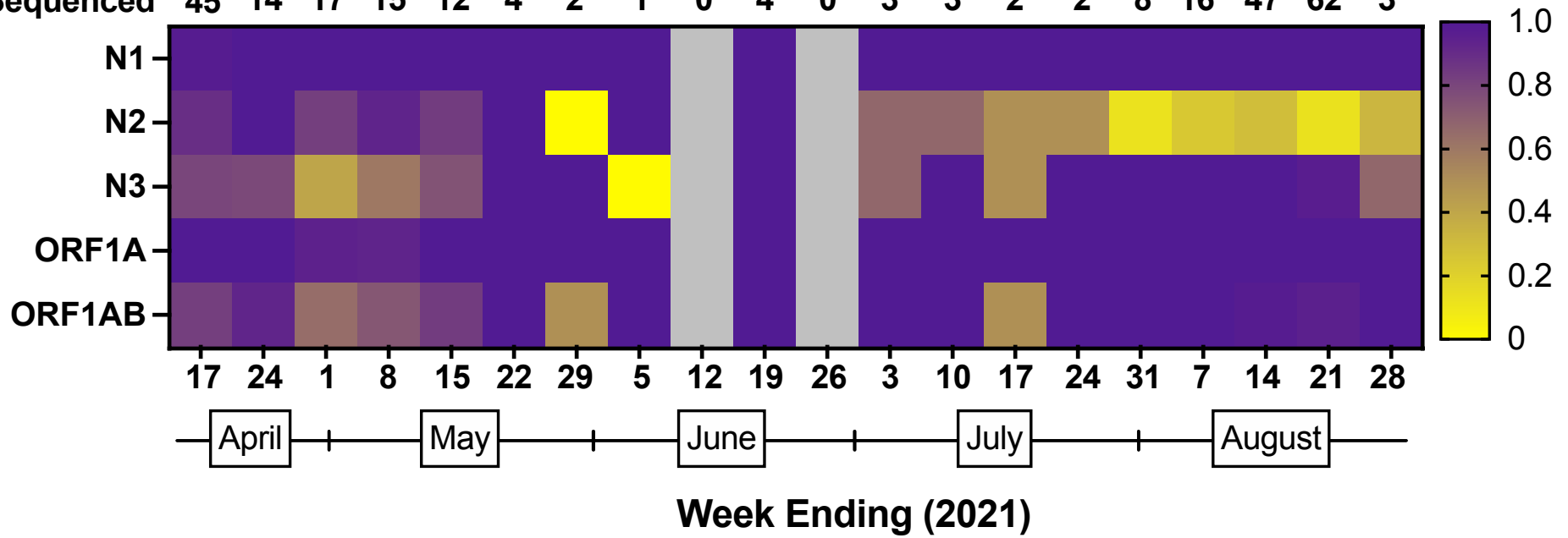

B

\section{Frequency of SARS-CoV-2 variants in NYC}

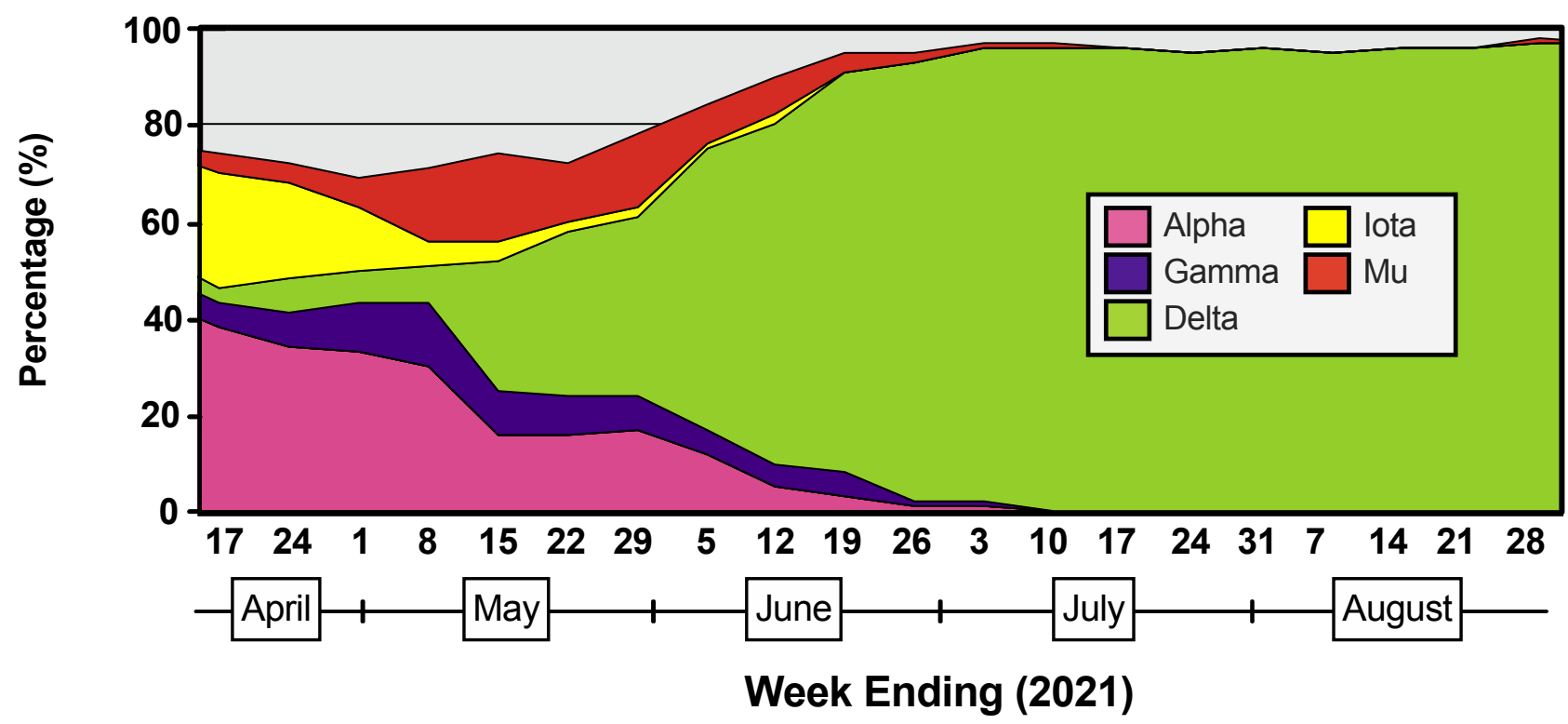


A

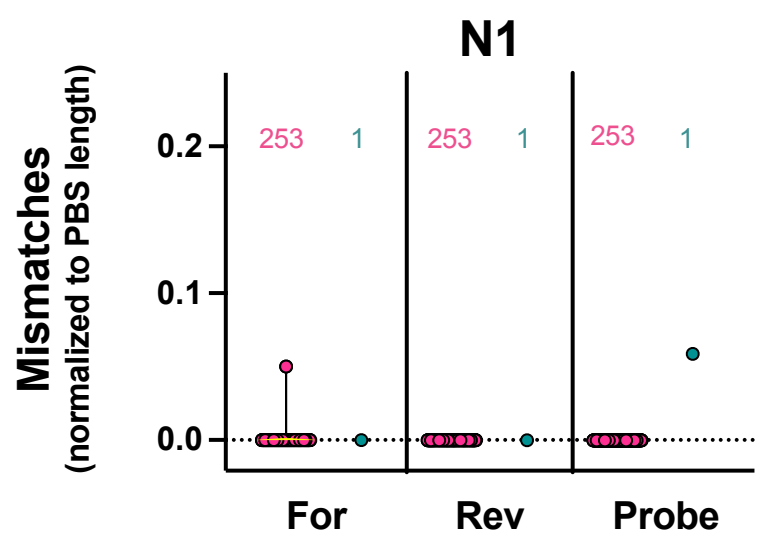

C

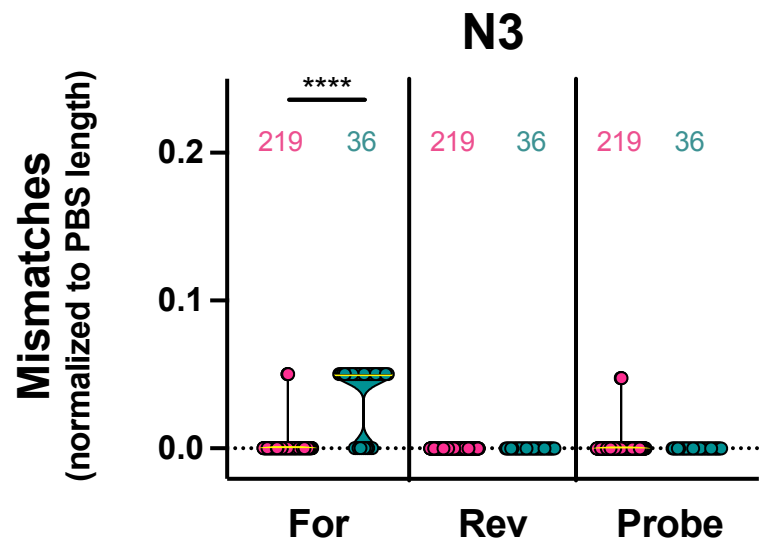

E

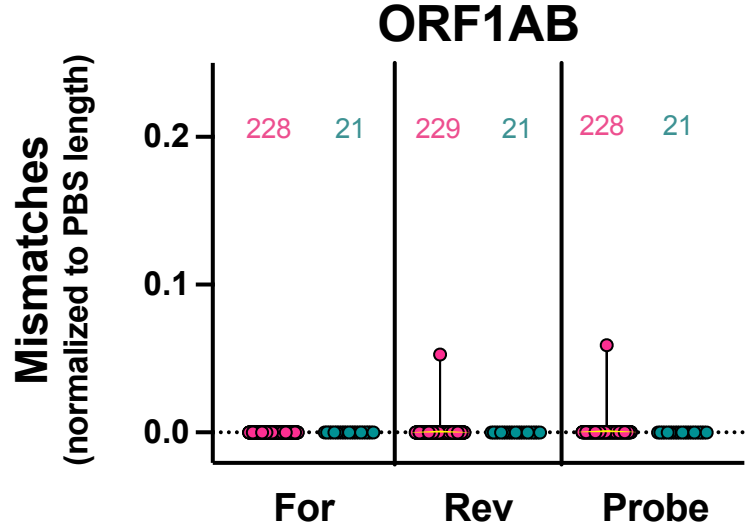

B

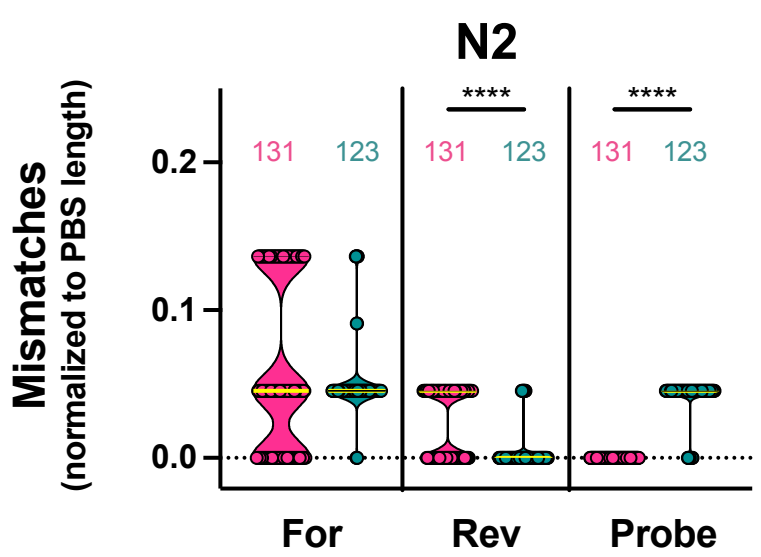

D

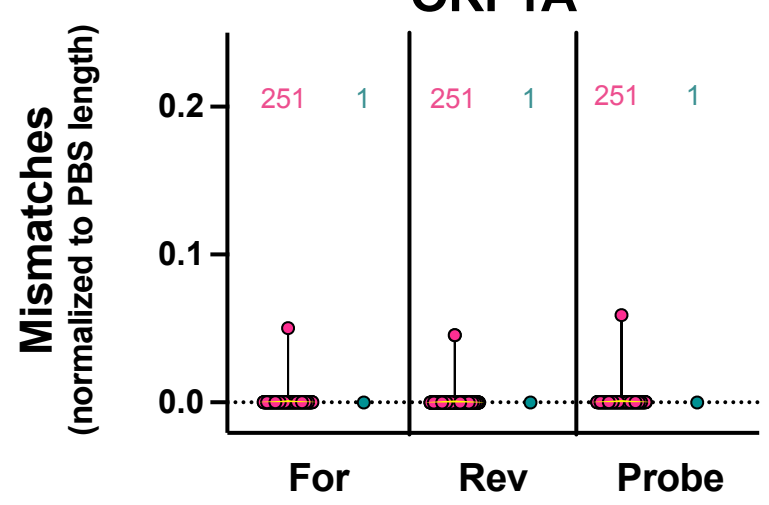


medRxiv preprint doi: https://doi.org/10.1101/2021.12.04.21267265; this version posted December 7, 2021. The copyright holder for this preprint (which was not certified by peer review) is the author/funder, who has granted medRxiv a license to display the preprint in perpetuity.

Figure 3

A

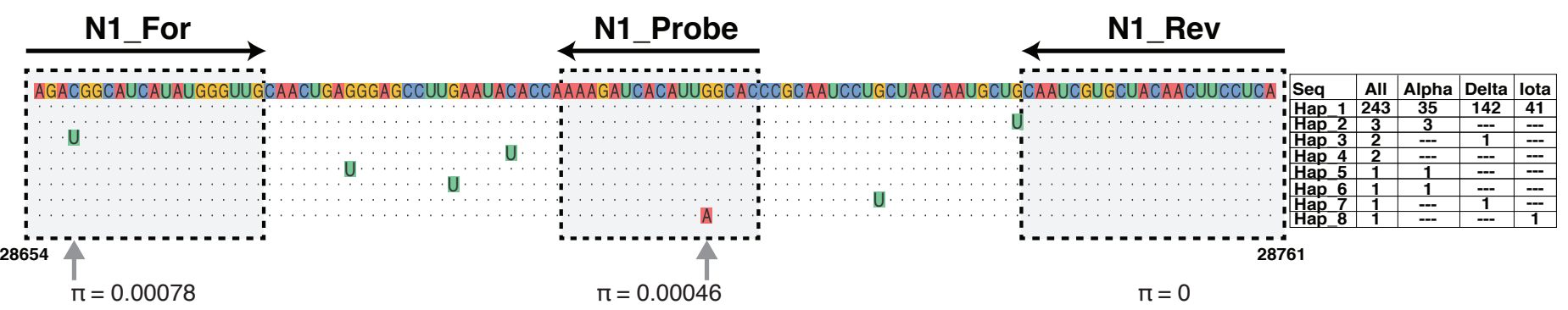

B
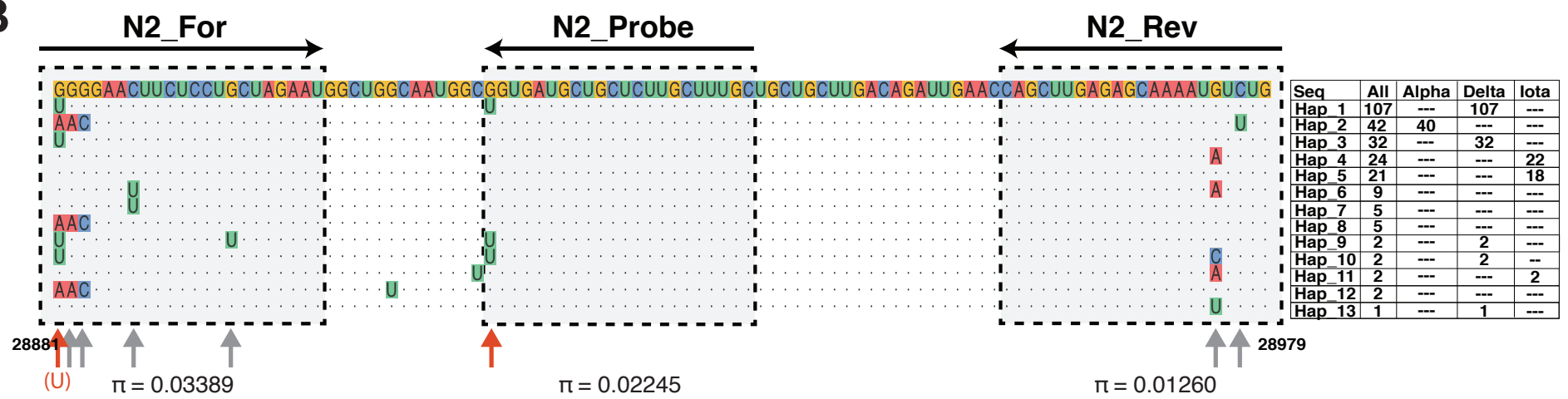

C

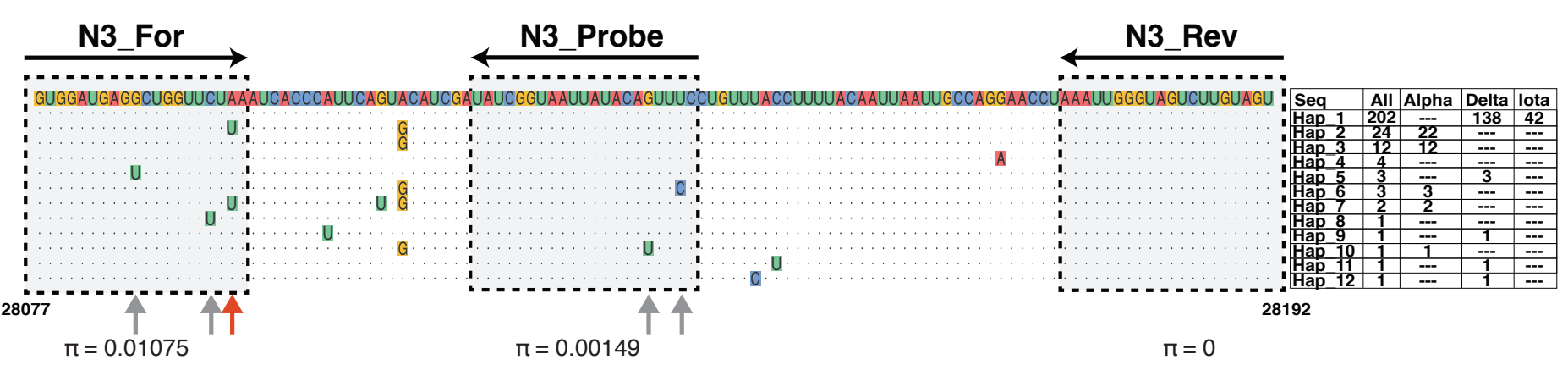

D
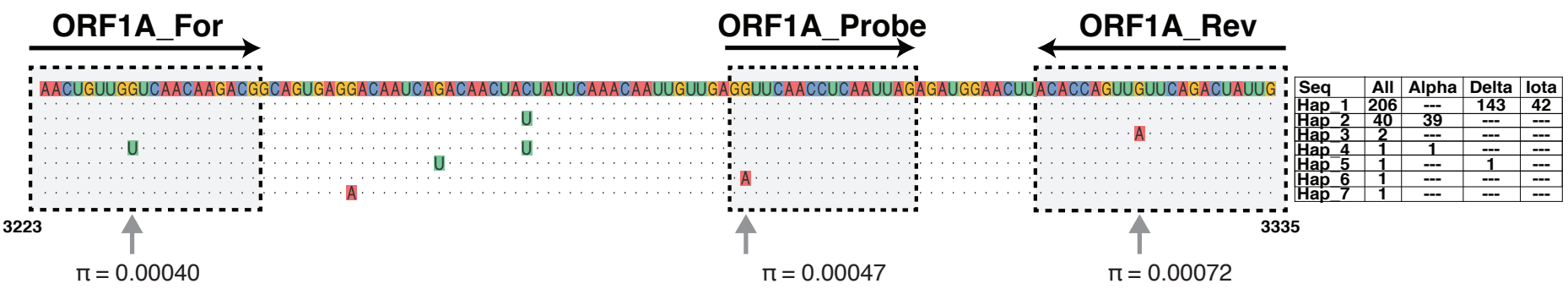

E

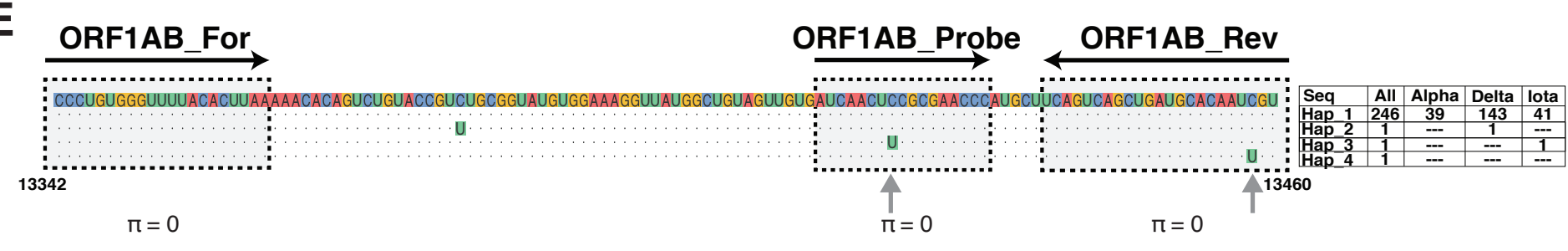


medRxiv preprint doi: https://doi.org/10.1101/2021.12 04.21267265; this version posted December 7, 2021. The copyright holder for this preprint (which was not certified by peer review) is the author/funder, who has granted medRxiv a license to display the preprint in perpetuity.

Figure 4

It is made available under a CC-BY-NC-ND 4.0 International license.

A

MSHS

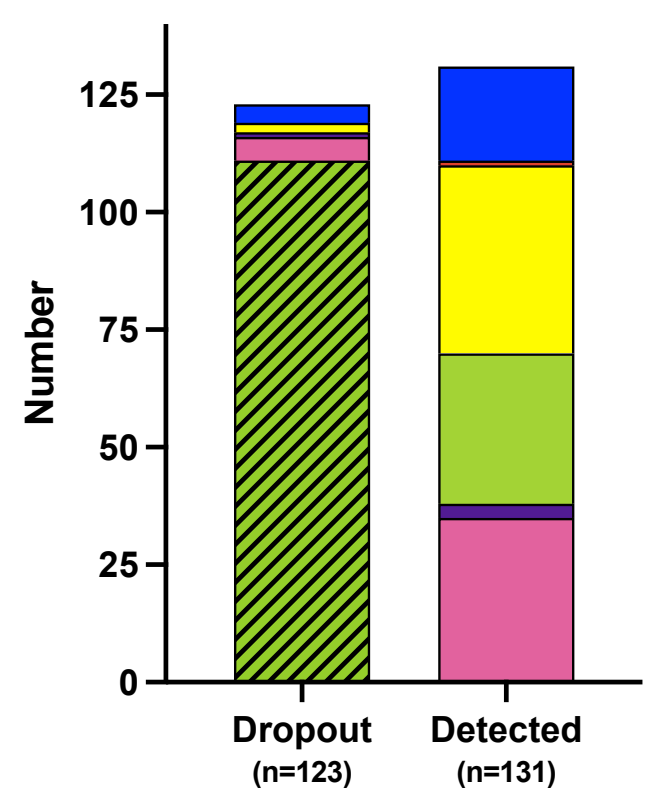

B

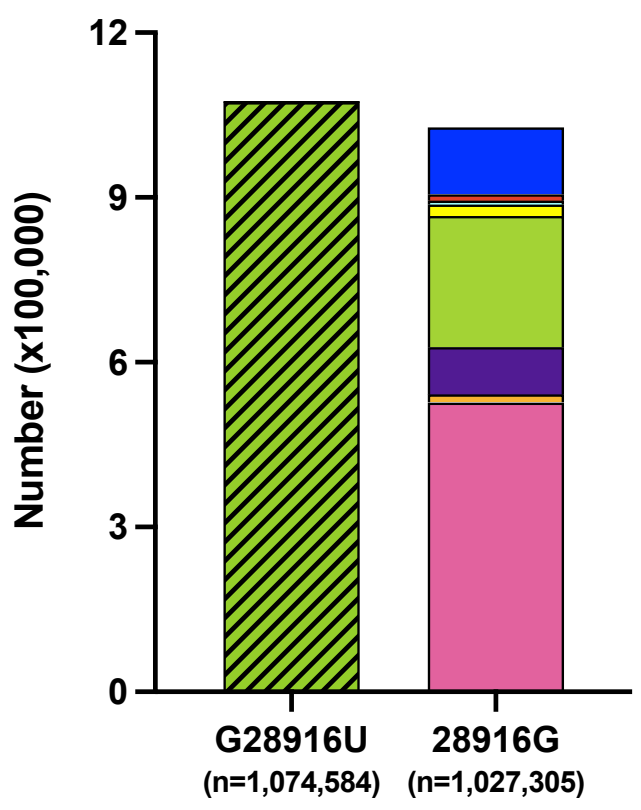

$\square$ Alpha

$\square$ Beta

$\square$ Gamma

$\square$ Delta

$\square$ lota

$\square$ Lambda

$\square \mathrm{Mu}$

$\square$ None

Q G28916U 